\title{
Breeding bird responses to juniper woodland expansion
}

\author{
STEVEN S. ROSENSTOCK AND CHARLES VAN RIPER III
}

Authors are research biologist, Arizona Game and Fish Department, 2221 West Greenway Road, Phoenix, Ariz. 85023; and station leader, U.S. Geological Survey Forest and Rangeland Ecosystem Science Center, Colorado Plateau Field Station, Box 5614, Northern Arizona University, Flagstaff, Ariz. 86011.

\begin{abstract}
In recent times, pinyon (Pinus spp.)-juniper (Juniperus spp.) woodlands have expanded into large portions of the Southwest historically occupied by grassland vegetation. From 1997-1998, we studied responses of breeding birds to one-seed juniper $(J$. monosperma) woodland expansion at 2 grassland study areas in northern Arizona. We sampled breeding birds in 3 successional stages along a grassland-woodland gradient: un-invaded grassland, grassland undergoing early stages of juniper establishment, and developing woodland. Species composition varied greatly among successional stages and was most different between endpoints of the gradient. Ground-nesting grassland species predominated in uninvaded grassland but declined dramatically as tree density increased. Tree- and cavity-nesting species increased with tree density and were most abundant in developing woodland. Restoration of juniper-invaded grasslands will benefit grasslandobligate birds and other wildlife.
\end{abstract}

Key Words: Juniperus monosperma, grassland, pinyon-juniper, Arizona, southwestern U.S., avian communities, succession

Since European settlement, pinyon (Pinus spp.)-juniper (Juniperus spp.) woodlands have expanded into large portions of the southwestern U.S. historically occupied by grassland (Miller 1921, Leopold 1951, Johnsen 1962, Rogers et al. 1984, Cinnamon 1988). Livestock grazing and fire suppression commonly are cited as causes of woodland expansion (Johnsen 1962, West 1984). Other factors linked to woodland expansion include climate change, long-term biogeographic patterns, and tree reestablishment following harvest by aboriginal Americans (Samuels and Betancourt 1982, Betancourt 1987, Jameson 1987).

The effects of juniper woodland expansion on wildlife have received little study and are not well understood. Because grassland birds are closely tied to habitat structure (Rotenberry and Wiens 1980, Wiens and Rotenberry 1981, Cody 1985), invasion of woody vegetation has serious implications for grassland avifauna (Knopf 1994). A better understanding of wildlife responses to woodland expansion will help resource managers design effec-

This study was undertaken with funds from the Federal Aid in Wildlife Restoration Act, Project W-78-R, of the Arizona Game and Fish Department. Warren Ballard, Bill Block, and David Willey provided valuable input on methodology and study design. Jim O'Haco provided access to lands owned by the Chevelon Butte/Chevelon Canyon Cattle Company. Jeri DeYoung, Bill Hudson, and Steve Mitchelson provided historical data from Wupatki National Monument and facilitated access for our research. Field support was provided by Debbie Brown, Tricia Hurley, Tammi Lesh, Christine Mandras, and Mike Rabe. Susi MacVean translated the abstract into Spanish.

Manuscript accepted 26 Aug. 2000.

\section{Res men}

En tiempos recientes, bosques de piñón (Pinus spp.) y enebro (Juniperus spp.) han invadido porciones grandes del Suroeste históricamente ocupadas por vegetación de prado. De 19971998, estudiamos el efecto de la expansión de bosque de enebro (J. monosperma) sobre una comunidad reproductiva de aves en 2 áreas de estudio en el norte de Arizona. Examinamos la comunidad de aves en 3 etapas de sucesión a lo largo de una gradiente de pradera-bosque: pradera no-invadida, pradera sujeta a etapas iniciales de establecimiento por enebro, y bosque en desarrollo. La composición de especies varió bastante entre etapas de sucesión pero la mayor variación ocurrió entre extremos del gradiente. Especies que anidan en el suelo de praderas predominaron en praderas no-invadidas, pero disminuyeron dramáticamente al aumentar la densidad de árboles. Especies que anidan en árboles y en cavidades aumentaron con mayor densidad de árboles y ocurrieron en mayor abundancia en bosque en desarrollo. La restauración de praderas invadidas por enebros será de beneficio para las aves, y otra vida silvestre, que dependen de praderas.

tive treatments and restoration programs for grassland and woodland habitats (Loftin et al. 1995).

Our objective in this study was to quantify effects of juniper woodland expansion on breeding bird communities in cold-temperate grasslands of northern Arizona. We predicted that development of woodland vegetation in grassland habitats would alter the breeding avifauna, with effects at both the community and species levels.

\section{Materials and Methods}

\section{Study Areas}

The study was conducted at 2 areas in northern Arizona, representing the transition zone between Plains and Great Basin grasslands (Brown 1982). Grasslands at both areas were undergoing succession to one-seed juniper (Juniperus monosperma (Engelm.) Sarg.) woodland and had not received treatments intended to control woody vegetation (e.g., herbicide application, prescribed fire, tree cutting, or mechanical control).

The Chevelon study area is located $38 \mathrm{~km}$ southeast of Winslow, Arizona (Lat $35^{\circ} 40^{\prime} \mathrm{N}$, Long $110^{\circ} 45^{\prime} \mathrm{W}$ ). Elevations range from $1,834-1,901 \mathrm{~m}$, with annual precipitation averaging $20.4 \mathrm{~cm}$. Soils are derived from limestone and sandstone parent 
materials. Dominant grass species include blue grama (Bouteloua gracilis (H.B.K.) Lag.), ring muhly (Muhlenbergia torreyana (Kunth) Hitchc.), and bottlebrush squirreltail (Sitanion hystrix (Nutt.) J.G. Smith). Scattered shrubs were present, primarily four-wing saltbush (Atriplex canescens (Pursh) Nutt.), Bigelow sagebrush (Artemisia bigelovii Gray), and Fremont barberry (Berberis fremontii Torr.). Colorado pinyon (Pinus edulis Engelm.) was present on widely scattered microsites with shallow, rocky soils. The area was grazed each year by cattle and horses, primarily during winter and spring.

The Wupatki study area is located in the north-central portion of Wupatki National Monument, $48 \mathrm{~km}$ northeast of Flagstaff, Ariz. (Lat $35^{\circ} 35^{\prime} \mathrm{N}$, Long $111^{\circ} 28^{\prime} \mathrm{W}$ ). Elevations range from 1,591-1,645 m, with annual precipitation averaging $20.0 \mathrm{~cm}$. Soils are derived from limestone and sandstone parent materials, overlain by a layer of volcanic cinders. Dominant grass species include needle-and-thread (Stipa comata Trin. and Rupr.), blue grama, galleta (Hilaria jamesii (Torr.) Benth.), black grama (B. eriopoda Torr.), and alkali sacaton (Sporobolus airoides Torr.). Shrubs were relatively sparse, consisting largely of rubber rabbitbrush (Chrysothamnus nauseosus (Pall.) Britton). Livestock have been excluded from Wupatki for ca. 20 years.

\section{Sampling Design}

We used aerial photos and ground surveys to identify and map grassland-woodland successional stages present on both study areas. Because juniper reproduction tends to occur as discrete, episodic events (Arnold et al. 1964), we delineated successional stages based upon overall physiognomy of the existing plant community, i.e., grass cover, tree size, and tree density. To minimize effects of environmental heterogeneity, we only mapped uniform vegetation types that were $>100$ ha in size, avoiding transition zones between successional stages.

Three successional stages were present on the study areas: (1) un-invaded grassland without juniper; (2) grassland undergoing early stages of juniper establishment, with scattered small junipers; and (3) developing woodland with abundant larger trees (Table 1). At both study areas, we randomly selected 4 replicate stands within each successional stage for bird and habitat sampling.

\section{Bird Sampling}

We used distance sampling (Buckland et al. 1993) to estimate breeding bird abun-

Table 1. Density and height of one-seed juniper (Juniperus monosperma) along a grassland-juniper woodland successional gradient at 2 northern Arizona study areas, 1997-1998. Values are means \pm 1 SE.

\begin{tabular}{lcc}
\hline \hline $\begin{array}{l}\text { Study area } \\
\text { Successional stage }\end{array}$ & Tree density & Tree height \\
\hline & $\left(\right.$ trees ha $\left.^{-1}\right)$ & $(\mathrm{m})$ \\
$\frac{(\text { Chevelon) }}{\text { Uninvaded grassland }}$ & 0 & - \\
Early establishment & $10.0 \pm 2.5$ & $2.0 \pm 0.2$ \\
Developing woodland & $92.3 \pm 8.8$ & $2.7 \pm 0.1$ \\
(Wupatki) & & \\
$\quad$ Uninvaded grassland & 0 & $2.3 \pm 0.2$ \\
Early establishment & $10.6 \pm 2.9$ & $3.4 \pm 0.1$ \\
Developing woodland & $41.9 \pm 6.2$ & \\
\hline
\end{tabular}

dance. Within each stand, we randomly located a $1-\mathrm{km}$ transect containing 5 sampling points spaced $250 \mathrm{~m}$ apart. Each point was sampled 3 times during June 1997 and June 1998, once by each of 3 observers. Count duration was 5-min per point. Sampling visits occurred 7-9 days apart, during a 2-hour period beginning at sunrise. Counts were not done during periods of rain or strong wind. Observers received extensive training in bird identification and distance estimation prior to field work (Kepler and Scott 1981). We collected distance measurements as grouped data (Buckland et al. 1993:110), where each bird detection was placed into 1 of 6 distance intervals $(0-5 \mathrm{~m}, 6-10 \mathrm{~m}$, $11-25 \mathrm{~m}, 26-50 \mathrm{~m}, 51-125 \mathrm{~m}$, and $>125$ $\mathrm{m})$. Observers used laser rangefinders and marker flags placed at known distances to assist in accurate distance estimation.

\section{Habitat Sampling}

Cover of herbaceous and shrub vegetation was measured on twenty, 50-m pointintercept transects, randomly located along each transect. Tree density and tree height were measured in a 4 X $50 \mathrm{~m}$ plot centered on the long axis of the intercept transect. Herbaceous vegetation was sampled each year. Trees and shrubs were sampled once during 1997.

\section{Data Analysis}

We used program DISTANCE (Thomas et al. 1999) to estimate bird density. Analyses were done only for species with $\geq 50$ detections. Because sample sizes were small, we pooled all detections to fit a common detection function, then used this function to derive density estimates for individual transects within years (Buckland et al. 1993:74). Candidate models were evaluated using Akaike's Information Criterion (AIC), $X^{2}$ goodness of fit statistics, and visual inspection of probability density functions fitted by DISTANCE.
We used Jaccard's index $(J)$ (Ludwig and Reynolds 1988) to assess similarity in bird species composition among stands representing different stages of woodland expansion. We also tallied proportions of species that belonged to each of 4 nesting guilds (ground, shrub, tree, or tree cavity). Guild classifications were based upon Ehrlich et al. (1988) and observational data collected during this study.

Species richness was estimated using a jackknife estimator (Burnham and Overton 1978), as implemented in program COMDYN (Nichols et al. 1996). This estimator is an extension of markrecapture theory and incorporates heterogeneity in species' detectability across multiple sampling events (Nichols et al. 1998).

We used Repeated Measures Analysis of Variance (Neter at al. 1990:1035) to test for overall differences in bird response variables among successional stages. If stage effects were significant $(\mathrm{P} \leq 0.05)$, and stage $X$ year interactions were not present $(P \geq 0.05)$, we used Scheffe's posthoc test to compare mean values among individual stages (Zar 1984:196). Differences among stages were considered significant at $\mathrm{P} \leq 0.05$. Data from the 2 study areas were analyzed separately, because of substantial edaphic differences affecting understory vegetation, woodland succession and potentially, breeding birds. Habitat characteristics among successional stages were summarized as means and associated standard errors; hypothesis tests on these data would have little value, as null hypotheses were known to be false $a$ priori (Johnson 1999).

\section{Results}

\section{Habitat Characteristics}

Habitat characteristics differed among successional stages at both sites. Habitat differences were most prevalent in the tree component, with one-seed juniper absent 
Table 2. Cover and height of grasses and shrubs along a grassland-juniper woodland successional gradient at 2 northern Arizona study areas, 1997-1998. Values are means \pm 1 SE.

\begin{tabular}{|c|c|c|c|c|}
\hline \multirow{2}{*}{$\begin{array}{l}\text { Study area } \\
\text { Successional stage }\end{array}$} & \multicolumn{2}{|c|}{ Grasses } & \multicolumn{2}{|c|}{ Shrubs } \\
\hline & Cover & Height & Cover & Height \\
\hline & $(\%)$ & $(\mathrm{cm})$ & $(\%)$ & $(\mathrm{cm})$ \\
\hline \multicolumn{5}{|l|}{ (Chevelon) } \\
\hline Un-invaded grassland & $28.8 \pm 2.9$ & $8.5 \pm 0.4$ & $5.2 \pm 0.4$ & $25.7 \pm 1.5$ \\
\hline Early establishment & $29.5 \pm 1.8$ & $10.1 \pm 0.3$ & $3.0 \pm 0.3$ & $35.5 \pm 1.1$ \\
\hline Developing woodland & $30.3 \pm 1.1$ & $7.6 \pm 0.4$ & $2.3 \pm 0.3$ & $49.3 \pm 10.3$ \\
\hline \multicolumn{5}{|l|}{ (Wupatki) } \\
\hline Un-invaded grassland & $57.1 \pm 1.8$ & $35.4 \pm 1.2$ & $0.3 \pm 0.1$ & $60.2 \pm 6.5$ \\
\hline Early establishment & $54.4 \pm 1.6$ & $37.2 \pm 0.6$ & $1.8 \pm 0.3$ & $53.6 \pm 1.9$ \\
\hline Developing woodland & $38.9 \pm 2.0$ & $25.8 \pm 0.7$ & $2.1 \pm 0.5$ & $44.5 \pm 1.7$ \\
\hline
\end{tabular}

in un-invaded grassland, but increasingly abundant in early establishment and developing woodland conditions (Table 1). Tree density was highest in developing woodland, with mean values of 92 and 42 trees/ha at Chevelon and Wupatki, respectively. Tree size also increased along the grassland-woodland gradient. The largest trees were present in developing woodland, averaging 2.7 and $3.4 \mathrm{~m}$ in height at Chevelon and Wupatki, respectively. Fewer differences were apparent in the grass and shrub components. Grass cover and height were greater at Wupatki than at Chevelon, but values were similar among stages within sites (Table 2). At Chevelon, shrub cover decreased along the grasslandwoodland gradient, but shrubs (primarily Fremont barberry) were much taller in the developing woodland stage. At Wupatki, shrub cover increased and shrub height decreased with woodland succession.

\section{Breeding Bird Community Attributes}

A total of 22 bird species was detected, 21 at Chevelon and 17 at Wupatki (Table 3 ). Most species occurred in 1 or 2 of the 3 successional stages present at each area. Composition of the breeding avifauna changed dramatically with woodland expansion. Values of $J$ ranged from $0.11-0.40$ and $0.13-0.52$ at Chevelon and Wupatki, respectively (Table 4). At both sites, endpoints of the successional gradient (un-invaded grassland versus developing woodland) had the fewest species in common. The greatest degree of overlap was found between un-invaded grassland and developing woodland at the Chevelon area, and between early establishment and developing woodland at Wupatki.

Species richness increased with woodland expansion, ranging from 4.4-19.5 and 3.0-10.5, at Chevelon and Wupatki, respectively (Fig. 1). Richness differed among stages at both sites (Chevelon: $F_{2,9}$ $=493.79, \mathrm{P}<0.0001$; Wupatki: $F_{2,9}$, $30.37, \mathrm{P} \leq 0.0001$ ), and was lowest in un- invaded grassland and highest in developing woodland. Species richness was significantly different between un-invaded grassland and developing woodland at both sites. Species richness was not significantly different in un-invaded grassland and early establishment woodland at Chevelon, but did differ at the Wupatki area. Richness differed in early establishment and developing woodland at Chevelon but did not differ at Wupatki.

Bird community composition changed dramatically along the grassland-woodland gradient. The proportion of groundnesting species differed among all stages at both sites (Chevelon: $F_{2,9}=43.1, \mathrm{P} \leq$

0.0001; Wupatki: $F_{2,9}=99.61, \mathrm{P} \leq$ $0.0001)$. Ground-nesters predominated in un-invaded grassland, but decreased sharply with increasing tree density (Fig. 2). The proportion of tree-nesting species also differed among all stages at both sites (Chevelon: $F_{2,9}=60.27, \mathrm{P} \leq 0.0001$; Wupatki: $\left.F_{2,9}=126.59, \mathrm{P} \leq 0.0001\right)$. Tree-nesters represented the bulk of the avifauna in developing woodland, but still were well-represented in early establishment woodland at both sites. Cavity-nesting species were relatively uncommon at Wupatki and did not differ among stages $\left(F_{2,9}=2.38, \mathrm{P}=0.15\right)$. Cavity-nesters made up a greater proportion of the avifauna at Chevelon and varied among stages $\left(F_{2,9}=46.20, \mathrm{P} \leq 0.0001\right)$. Like tree nesters, cavity-nesting species were most common in developing woodland and rare or absent in earlier successional stages. Proportions of shrub-nesting species did not vary significantly among stages at either area (Chevelon: $F_{2,9}=$ 4.13, $\mathrm{P}=0.053$; Wupatki: $F_{2,9}=4.07, \mathrm{P}=$ $0.054)$.

\section{Bird Abundance}

The majority of bird species occurred in relatively low numbers; only 12 species were detected often enough for density

Table 3. Occurrence of 22 breeding bird species along a grassland-juniper woodland successional gradient at 2 northern Arizona study areas, 1997-1998. Stages were: 1 = un-invaded grassland, 2 = early woodland establishment, 3 = developing woodland.

\begin{tabular}{|c|c|c|c|c|c|c|}
\hline \multirow[b]{2}{*}{ Species } & \multicolumn{3}{|c|}{ Chevelon } & \multicolumn{3}{|c|}{ Wupatki } \\
\hline & 1 & 2 & 3 & 1 & 2 & 3 \\
\hline Mourning dove (Zenaida macroura L.) & & $\sqrt{ }$ & $\sqrt{ }$ & & $\sqrt{ }$ & $\sqrt{ }$ \\
\hline $\begin{array}{l}\text { Ash-throated flycatcher (Myiarchus cinerascens } \\
\text { Lawrence) }\end{array}$ & & & $\sqrt{ }$ & & & $\sqrt{ }$ \\
\hline Cassin's kingbird (Tyrannus vociferans Swainson) & & & $\sqrt{ }$ & & & $\sqrt{ }$ \\
\hline Horned lark (Eremophila alpestris L.) & $\sqrt{ }$ & $\sqrt{ }$ & $\sqrt{ }$ & $\sqrt{ }$ & $\sqrt{ }$ & $\sqrt{ }$ \\
\hline Scrub jay (Aphelocoma coerulescens Bosc) & & & $\sqrt{ }$ & & & \\
\hline Pinyon jay (Gymnorhinus cyanocephalus Wied) & & & $\sqrt{ }$ & & $\sqrt{ }$ & $\sqrt{ }$ \\
\hline Plain titmouse (Parus inornatus Gambel) & & & $\sqrt{ }$ & & & $\sqrt{ }$ \\
\hline Common bushtit (Psaltriparus minimus Townsend) & & & $\sqrt{ }$ & & & $\sqrt{ }$ \\
\hline Bewick's wren (Thyromanes bewickii Audubon) & & $\sqrt{ }$ & $\sqrt{ }$ & & & \\
\hline Townsend's solitaire (Myadestes townsendi Audubon) & & & & & $\sqrt{ }$ & \\
\hline Mountain bluebird (Sialia currucoides Bechstein) & & $\sqrt{ }$ & $\sqrt{ }$ & & & \\
\hline Western bluebird (Sialia mexicana Swainson) & & & $\sqrt{ }$ & & & \\
\hline Northern mockingbird (Mimus polyglottos L.) & $\sqrt{ }$ & $\sqrt{ }$ & $\sqrt{ }$ & & $\sqrt{ }$ & $\sqrt{ }$ \\
\hline Loggerhead shrike (Lanius ludovicianus L.) & $\sqrt{ }$ & $\sqrt{ }$ & $\sqrt{ }$ & & $\sqrt{ }$ & $\sqrt{ }$ \\
\hline Black-throated sparrow (Amphispiza bilineata Cassin) & & $\sqrt{ }$ & $\sqrt{ }$ & & & \\
\hline Lark sparrow (Chondestes grammacus Say) & $\sqrt{ }$ & $\sqrt{ }$ & $\sqrt{ }$ & & $\sqrt{ }$ & $\sqrt{ }$ \\
\hline Spotted towhee (Pipilo erythrophthalmus L.) & & & $\sqrt{ }$ & & & \\
\hline Chipping sparrow (Spizella passerina Bechstein) & & & $\sqrt{ }$ & & & $\sqrt{ }$ \\
\hline Scott's oriole (Icterus parisorum Bonaparte) & & $\sqrt{ }$ & $\sqrt{ }$ & & $\sqrt{ }$ & $\sqrt{ }$ \\
\hline Brown-headed cowbird (Molothrus ater Boddaert) & & & $\sqrt{ }$ & & & $\sqrt{ }$ \\
\hline Eastern meadowlark (Sturnella magna L.) & $\sqrt{ }$ & $\sqrt{ }$ & & $\sqrt{ }$ & $\sqrt{ }$ & $\sqrt{ }$ \\
\hline Western meadowlark (Sturnella neglecta Audubon) & $\sqrt{ }$ & $\sqrt{ }$ & & $\sqrt{ }$ & $\sqrt{ }$ & $\sqrt{ }$ \\
\hline
\end{tabular}


Table 4. Similarity of breeding bird species composition along a grassland-juniper woodland successional gradient at 2 northern Arizona study areas, 1997-1998. Values are mean Jaccard index $(J)$ values across years \pm 1 SE. Potential index values range from $0-1$, representing no species in common and total overlap, respectively.

\begin{tabular}{lcc}
\hline \hline $\begin{array}{l}\text { Study area } \\
\text { Successional stage }\end{array}$ & Uninvaded grassland & Early establishment \\
\hline $\begin{array}{c}\text { (Chevelon) } \\
\text { Early establishment }\end{array}$ & $0.40 \pm .04$ & \\
Developing woodland & $0.11 \pm .01$ & $0.25 \pm .01$ \\
(Wupatki) & $0.26 \pm .02$ & \\
$\quad$ Early establishment & $0.13 \pm .01$ & $0.52 \pm .02$ \\
$\quad$ Developing woodland & & \\
\hline
\end{tabular}

estimation. Three ground-nesting grassland species were most strongly associated with un-invaded grassland and early establishment stages (Tables 5 and 6). Eastern and western meadowlarks were found in un-invaded grassland and early establishment woodland at Chevelon, and in all 3 successional stages at Wupatki. At both sites, meadowlarks were most abundant in early establishment woodlands. Horned larks were present in all successional stages at both sites, but were most abundant in un-invaded grassland. One groundnesting species (spotted towhee) was present only in developing woodland at Chevelon.

We obtained density estimates for 1 shrub-nesting species present in early establishment and developing woodlands. At Chevelon, lark sparrows were present in all stages and were most abundant in developing woodland. At Wupatki, lark sparrows were found in early establishment and developing woodland, and were most abundant in the latter.

Six tree-nesting species had adequate sample sizes to estimate density. These species were largely restricted to developing woodland at Chevelon, but did occur in early establishment woodland at Wupatki. Common bushtits were present only in developing woodland at both sites. Chipping sparrows were found only in developing woodland at Chevelon. Northern mockingbirds were present in all successional stages at Chevelon, but only in early establishment and developing woodland at Wupatki. At both sites, mockingbirds were most abundant in developing woodland. At Wupatki, mourning doves were similarly abundant in early establishment and developing woodland. Pinyon jays were found only in developing woodland at Chevelon and were equally abundant in early establishment and developing woodland at Wupatki. Scott's orioles were found in early establishment and developing woodland at both sites, but were most abundant in the latter. Cavity-nesting species were largely restricted to developing woodland.
Ash-throated flycatchers were present in developing woodland at both sites. Bewick's wren occurred in early establishment and developing woodland at the Values are means across years $\pm 1 \mathrm{SE}$.

${ }^{2} \mathrm{a}=$ absent from all transects. Values are means across years $\pm 1 \mathrm{SE}$.

$2 \mathrm{a}=$ absent from all transects.
Chevelon area, being most abundant in the latter successional stage.

\section{Discussion}

Woodland expansion had a strong and consistent influence on grassland avifauna. Ground-nesting grassland species predominated in un-invaded grassland, but declined as tree density increased. The proportion of tree- and cavity-nesting species increased with woodland succession and was highest in developing woodland. Shrub-nesters did not respond to woodland expansion, probably because shrubs were relatively sparse on our study

Table 5. Density estimates of 11 breeding bird species from 4 nesting guilds along a grasslandjuniper woodland successional gradient at Chevelon study area, northern Arizona, 1997-1998.

\begin{tabular}{|c|c|c|c|}
\hline $\begin{array}{l}\text { Guild } \\
\text { Species }\end{array}$ & $\begin{array}{l}\text { Un-invaded } \\
\text { grassland }\end{array}$ & $\begin{array}{c}\text { Early } \\
\text { establishment }\end{array}$ & $\begin{array}{c}\text { Developing } \\
\text { woodland }\end{array}$ \\
\hline & & - $\left(\right.$ birds ha $\left.{ }^{-1}\right)$ & \\
\hline \multicolumn{4}{|l|}{ (Ground-nester) } \\
\hline Meadowlark 1 & $0.02 \pm 0.01$ & $0.05 \pm 0.02$ & $a^{2}$ \\
\hline Horned lark & $0.43 \pm 0.03$ & $0.37 \pm 0.03$ & $0.04 \pm 0.02$ \\
\hline Spotted towhee & $\mathrm{a}$ & $\mathrm{a}$ & $0.08 \pm 0.02$ \\
\hline \multicolumn{4}{|l|}{ (Shrub-nester) } \\
\hline Lark sparrow & $\mathrm{p}^{3}$ & $0.04 \pm 0.01$ & $0.21 \pm 0.03$ \\
\hline \multicolumn{4}{|l|}{ (Tree-nester) } \\
\hline Pinyon jay & a & a & $0.03 \pm 0.01$ \\
\hline Common bushtit & $\mathrm{a}$ & $\mathrm{a}$ & $0.19 \pm 0.07$ \\
\hline Northern mockingbird & $\mathrm{p}$ & $0.12 \pm 0.02$ & $0.25 \pm 0.05$ \\
\hline Chipping sparrow & $\mathrm{a}$ & a & $0.23 \pm 0.03$ \\
\hline Scott's oriole & $\mathrm{a}$ & $\mathrm{p}$ & $0.06 \pm 0.01$ \\
\hline \multicolumn{4}{|l|}{ (Cavity-nester) } \\
\hline Ash-throated flycatcher & $\mathrm{a}$ & $\mathrm{a}$ & $0.10 \pm 0.02$ \\
\hline Bewick's wren & $\mathrm{a}$ & $\mathrm{p}$ & $0.07 \pm 0.02$ \\
\hline
\end{tabular}

${ }_{2}$ Includes eastern and western species, which often could not be distinguished.

$3 \mathrm{p}=$ present on 1 or more transects, but not detected during sampling visits.

Table 6. Density estimates of 9 breeding bird species from 4 nesting guilds along a grasslandjuniper woodland successional gradient at Wupatki study area, northern Arizona, 1997-1998.

\begin{tabular}{|c|c|c|c|}
\hline $\begin{array}{l}\text { Guild } \\
\quad \text { Species }\end{array}$ & $\begin{array}{l}\text { Uninvaded } \\
\text { grassland }\end{array}$ & $\begin{array}{c}\text { Early } \\
\text { establishment }\end{array}$ & $\begin{array}{l}\text { Developing } \\
\text { woodland }\end{array}$ \\
\hline & & - $\left(\right.$ birds ha $\left.{ }^{-1}\right)$ & \\
\hline \multicolumn{4}{|l|}{ (Ground-nester) } \\
\hline Meadowlark $^{1}$ & $0.06 \pm 0.02$ & $0.25 \pm 0.05$ & $0.10 \pm 0.03$ \\
\hline Horned lark & $0.33 \pm 0.02$ & $0.29 \pm 0.02$ & $0.08 \pm 0.01$ \\
\hline \multicolumn{4}{|l|}{ (Shrub-nester) } \\
\hline Lark sparrow & $a^{2}$ & $\mathrm{p}^{3}$ & $0.21 \pm 0.02$ \\
\hline \multicolumn{4}{|l|}{ (Tree-nester) } \\
\hline Mourning dove & a & $0.16 \pm 0.06$ & $0.13 \pm 0.04$ \\
\hline Pinyon jay & $\mathrm{a}$ & $0.06 \pm 0.04$ & $0.06 \pm 0.02$ \\
\hline Common bushtit & a & a & $0.04 \pm 0.04$ \\
\hline Northern mockingbird & $\mathrm{a}$ & $0.06 \pm 0.01$ & $0.23 \pm 0.03$ \\
\hline Scott's oriole & $\mathrm{a}$ & $0.02 \pm 0.01$ & $0.07 \pm 0.02$ \\
\hline \multicolumn{4}{|l|}{ (Cavity-nester) } \\
\hline Ash-throated flycatcher & a & a & $0.03 \pm 0.01$ \\
\hline
\end{tabular}

${ }^{1}$ Includes eastern and western species, which often could not be distinguished.

$3 \mathrm{p}=$ present on 1 or more transects, but not detected during sampling visits. 


\section{Uninvaded grassland \\ $\square \subset$ Early establishment \\ $\bowtie \bowtie \triangle$ Developing woodland}

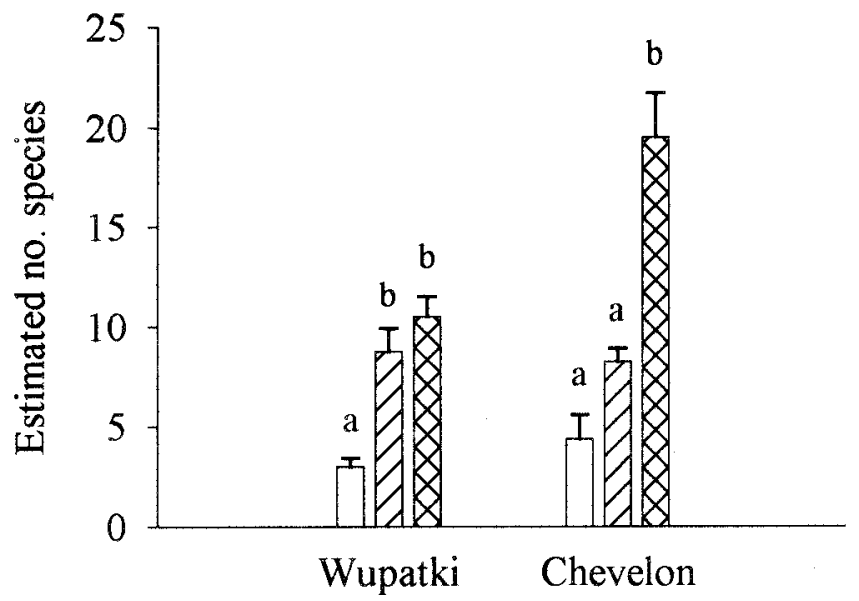

\section{Study Area}

Fig. 1. Breeding bird species richness (mean $\pm 1 \mathrm{SE}$ ) along a grassland-juniper woodland successional gradient at 2 northern Arizona study sites, 1997-1998. Significant differences within sites (repeated measures ANOVA followed by Scheffe's post-hoc means test, $\mathbf{P} \leq$ 0.05) are indicated by lowercase letters above histogram bars.

areas, and shrub density and shrub size were similar among successional stages. The breeding avifauna changed dramatically with woodland succession; differences were most pronounced between endpoints of our gradient (un-invaded grassland versus developing woodland). Differences in species composition within successional woodlands appeared proportional to the magnitude of change in the tree component. For example, at the Chevelon area, tree density increased by nearly an order of magnitude between early establishment and developing woodland, and species overlap was low $(J=$ $0.25)$. In contrast, there was only a 4-fold difference in tree density between these stages at Wupatki, and species overlap was much higher $(J=0.52)$. Studies in other North American grasslands also have reported substantial avifaunal changes in response to woodland expansion. In southern Arizona, invasion of mesquite (Prosopis spp.) increased breeding bird species richness, but decreased habitat suitability for several grassland species (Lloyd et al. 1998). Shelterbelt plantings in the Great Plains and midwestern U.S. have been colonized by bird species historically associated with savanna and deciduous forests (Martin 1981, Yahner 1983, Knopf 1994).

The avian community changes that we observed were consistent with results of previous studies in northern Arizona. LaRue (1994) reported that horned larks and meadowlarks were the dominant breeding species on mined areas revegetated to grassland, whereas juniper-invaded grasslands supported tree-nesting species including northern mockingbirds, loggerhead shrikes, chipping sparrows, and Scott's orioles. Prior breeding bird surveys at Wupatki found 17 species (primarily tree-nesters) at a juniper savannah area, compared to 8 species at a grassland area (Beatty 1978). Within Southwestern pinyon-juniper woodlands, breeding bird diversity and abundance have been positively correlated with tree density and tree size (Masters 1979, Sedgwick 1987, LaRue 1994).

The inverse of the woodland expansion pattern has been found in studies of breeding birds in treated pinyon-juniper woodlands; where fire, herbicides, and mechanical treatments have been used to create openings dominated by herbaceous and shrub vegetation. Treated areas were dominated by ground-nesting and grassland bird species (Grue 1977, Kruse et al. 1979, LaRue 1994). Diversity was highest in undisturbed woodlands and at woodland edges adjacent to treated areas (O'Meara et al. 1981, Sedgwick and Ryder 1987). Foliage and cavity nesting species were more abundant in or restricted to untreated or lightly treated woodlands (Sedgwick and Ryder 1987, La Rue 1994).

Responses of breeding birds to woodland expansion likely are driven by linkages between individual species and floristic and physiognomic habitat features (Rotenberry and Wiens 1980, Wiens and Rotenberry 1981, Cody 1985). The addition of a tree component provides nesting and foraging opportunities for woodland species, but reduces habitat suitability for grassland-obligate birds. The presence of woody vegetation may further influence community structure by altering predation risk for "cover-dependent" versus "coverindependent" bird species (Lima and Valone 1991).

\section{Conclusions and Management Recommendations}

Woodland expansion is an important issue in Southwestern grasslands, particularly on public lands (Loftin et al. 1995). While the grassland bird species that we studied are not currently listed as threatened, endangered, or "species of concern," continued expansion of juniper in northern Arizona grasslands will result in additional, substantial habitat change over the long-term and reductions in the numbers of grassland-obligate birds.

Our results suggest that removal or reduction of invasive juniper will improve breeding habitat for horned larks, meadowlarks, and other grassland-obligate birds in northern Arizona. Grassland restoration would likely benefit other wildlife species. Juniper woodland expansion has been found to decrease habitat quality for pronghorn (Antilocapra americana Ord) and increase susceptibility to predation (Alexander and Ockenfels 1994, R. Ockenfels, Arizona Game and Fish Dept., pers. comm.). Anecdotal observations made during this study also suggest that woodland expansion is detrimental to Gunnison's prairie dogs (Cynomys gunnisoni Baird). Active prairie dog towns were present on or near all transects in uninvaded grassland, but were absent in successional woodlands.

Several factors should be considered by resource managers planning grassland restoration projects. True "restoration" is likely possible only in areas along the grassland-woodland interface that historically were occupied by grassland vegetation. Type conversions in higher elevation "true" pinyon-juniper woodlands are expensive and generally have short-lived effects. A density of $\geq 10$ juniper trees ha ${ }^{-1}$ is an approximate threshold at which habi- 

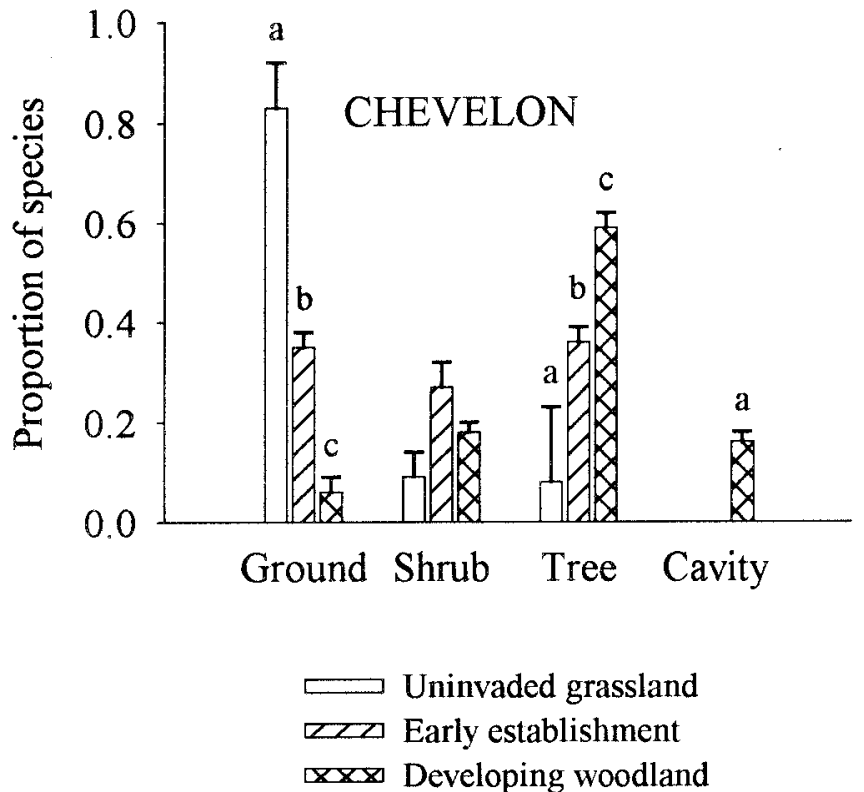

a

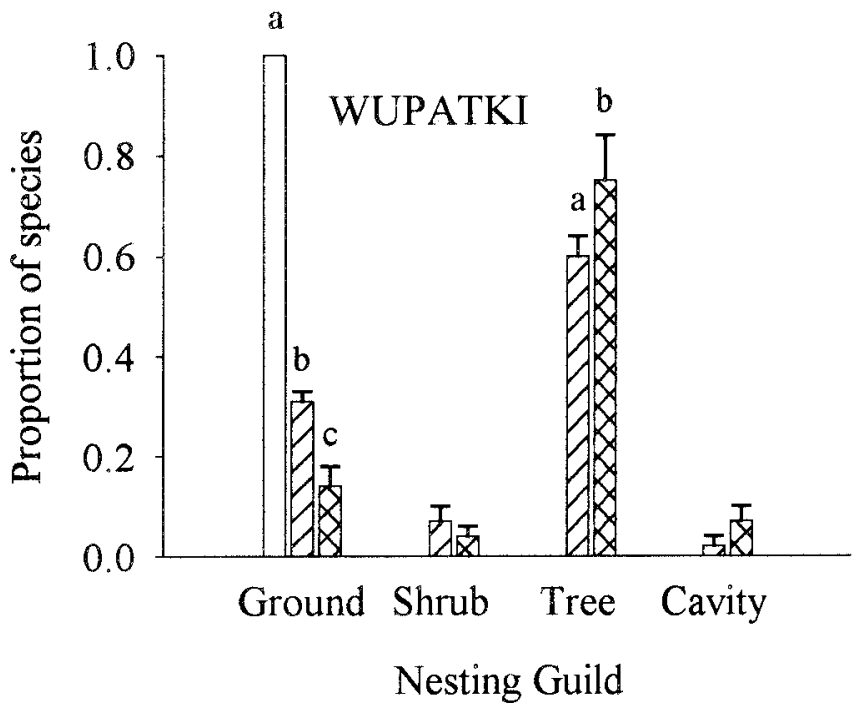

Fig. 2. Breeding bird nesting guild composition along a grassland-juniper woodland successional gradient at 2 northern Arizona study sites, 1997-1998. Values are mean proportion of species belonging to each guild $\pm 1 \mathrm{SE}$. Missing bars reflect zero values for particular successional stages. Significant differences among successional stages within sites (repeated measures ANOVA followed by Scheffe's post-hoc means test, $P \leq 0.05$ ) are indicated by lowercase letters above histogram bars.

tat suitability for grassland species declines and at which restoration treatments should be considered. Priority should be given to sites that have a well-established perennial grass component, as artificial seeding and surface treatments needed to establish grasses will greatly inflate project cost. Artificial seeding may be difficult or impractical where upper soil horizons have been lost to erosion. Shrubs that provide nesting cover and song perches for breeding birds (e.g., four-wing saltbush and
Arnold, J.F., D.A. Jameson, and E.H. Reid. 1964. The pinyon-juniper type of Arizona: Effects of fire, grazing, and tree control. USDA For. Serv. Production Res. Rep. 84. Washington, D.C.

Beatty, L. 1978. Natural resource survey and analysis of Sunset Crater and Wupatki National Monuments. Office of Natural Resource Manage., Nat. Park Serv., Southwestern Region, Denver, Colo.

Betancourt, J.L. 1987. Paleoecology of pinyon-juniper woodlands: a summary, pp. 129-139. In: R.L. Everett (ed.), Proceedings: pinyon-juniper conference. USDA Forest Serv. Gen. Tech. Rep. INT-215, Ogden, Ut.

Brown, D.E. 1982. Plains and Great Basin grassland. Desert Plants 1-4:115-121.

Buckland, S.T., D.R. Anderson, K.P. Burnham, and J. L. Laake. 1993. Distance sampling: estimating abundance of biological populations. Chapman and Hall, New York, N.Y.

Burnham, K.P. and W.S. Overton. 1978. Estimation of the size of a closed population when capture probabilities vary among animals. Biometrika 65:625-633.

Cinnamon, S.K. 1988. The plant community of Cedar Canyon, Wupatki National Monument, as influenced by prehistoric and historic environmental change. M.Sc. thesis, Northern Arizona Univ., Flagstaff, Ariz.

Cody, M.L. 1985. An introduction to habitat selection in birds, pp. 4-46. In: M. L. Cody (ed.), Habitat selection in birds. Academic Press, San Diego, Calif.

Ehrlich, P.A., D.S. Dobkin, and D. Wheye. 1988. The birder's handbook: a field guide to the natural history of North American birds. Simon and Schuster, New York, N.Y.

Grue, C.E. 1977. The impact of power line development on birds in central Arizona. M.Sc. thesis, Northern Arizona Univ., Flagstaff, Ariz.

Jameson, D.A. 1987. Climax or alternative steady states in woodland ecology, pp. 9-13. In R.L. Everett (ed.), Proceedings: pinyonjuniper conference. USDA For. Serv. Gen. Tech. Rep. INT-215, Ogden, Ut.

Johnsen, T.N., Jr. 1962. One-seed juniper invasion of northern Arizona grasslands. Ecol. Monogr. 32:187-207.

Johnson, D.H. 1999. The insignificance of statistical significance testing. J. Wildl. Manage. 63:763-772.

Kepler, C.B., and J.M. Scott. 1981. Reducing count variability by training observers. Studies in Avian Biol. 6:366-371.

Knopf, F.L. 1994. Avian assemblages on altered grasslands. Studies in Avian Biol. 15:247-257.

Kruse, W.H., R.P. Balda, M.J. Simono, A.M. Macrander, and C.D. Johnson. 1979. Community development in two adjacent pinyon-juniper eradication areas twenty-five years after treatment. J. Environ. Manage. 8:237-247.

Alexander, A. and R. A. Ockenfels. 1994. Juniper densities relative to pronghorn use in central Arizona. Proc. Pronghorn Workshop $16: 76-85$.
LaRue, C.T. 1994. Birds of northern Black Mesa, Navajo County, Arizona. Great Basin Natur. 54:1-63. 
Leopold, L.B. 1951. Vegetation of southwestern watersheds in the nineteenth century Geographical Rev. 41:295-316.

Lima, S.L. and T.J. Valone. 1991. Predators and avian community organization: an experiment in a semi-desert grassland. Oecologia 86:105-112.

Lloyd, J., R.W. Mannan, S. DeStefano, and C. Kirkpatrick. 1998. The effects of mesquite invasion on a southeastern Arizona grassland bird community. Wilson Bull. 110:403-408.

Loftin, S.R., R. Aguilar, A.L. ChungMacCoubrey, and W.A. Robbie. 1995. Desert grassland and shrubland ecosystems, pp. 80-94. In: D.M. Finch and J.A. Tainter (eds.), Ecology, diversity, and sustainability of the middle Rio Grande Basin. USDA For. Serv. Gen. Tech. Rep. RM-268, Fort Collins, Colo.

Ludwig, J.A. and J.F. Reynolds. 1988. Statistical ecology: a primer on methods and computing. John Wiley and Sons, New York, N.Y.

Martin, T.E. 1981. Limitation in small habitat islands: chance or competition. Auk 98:715-734.

Masters, N.L. 1979. Breeding birds of pinyonjuniper woodland in north central Arizona. M.Sc. thesis, Northern Arizona Univ., Flagstaff, Ariz.
Miller, F.H. 1921. Reclamation of grasslands by Utah juniper on the Tusuyan National Forest, Arizona. J. For. 19:647-651.

Neter, J., W. Wasserman, and M.H. Kutner. 1990. Applied linear statistical models, $3^{\text {rd }}$ ed. Irwin Press, Boston, Mass.

Nichols, J.D., T. Boulinier, J.E. Hines, K.H. Pollock, and J.R. Sauer. 1996. Inference procedures for animal community dynamics: changes in species richness over time and space. http://www.mbr.nbs.gov/software.html.

Nichols, J.D., T. Bouliner, J.E. Hines, K.H. Pollock, and J.R. Sauer. 1998. Estimating rates of local species extinction, colonization, and turnover in animal communities. Ecol. Appl. 8:1213-1225.

O'Meara, T.E., J B. Haufler, L.H. Stelter, and J.G. Nagy. 1981. Nongame responses to chaining of pinyon-juniper woodlands. J. Wildl. Manage. 45:381-389.

Rotenberry, J T. and J.A. Wiens. 1980. Habitat structure, patchiness, and avian communities in North American steppe vegetation: a multivariate analysis. Ecol. 61:1228-1250.

Rogers, G.F., H.E. Malde, and R.M. Turner. 1984. Bibliography of repeat photography for evaluating landscape change. Univ. of Utah Press, Salt Lake City, Ut.

Samuels, M.D. and J.L. Betancourt. 1982. Modeling the long-term effects of fuelwood harvests on pinyon-juniper woodlands. Environ. Manage. 6:505-515.
Sedgwick, J.A. 1987. Avian habitat relationships in pinyon-juniper woodland. Wilson Bull. 99:413-431.

Sedgwick, J.A. and R.A. Ryder. 1987. Effects of chaining pinyon-juniper on nongame wildlife, pp. 541-551. In: R.L. Everett (ed.), Proceedings: pinyon-juniper conference. USDA For. Serv. Gen. Tech. Rep. INT-215, Ogden, Ut.

Thomas, L., J. Laake, and J. Derry. 1999. DISTANCE v3.5. Research Unit for Wildl. Pop. Assessment, Univ. of St. Andrews, Scotland.

West, N.E. 1984. Successional patterns and productivity potentials of pinyon-juniper ecosystems, pp. 1301-1322. In: Developing strategies for rangeland management. Westview Press, Boulder, Colo.

Wiens, J.A. and J.T. Rotenberry. 1981. Habitat associations and community structure of birds in shrubsteppe environments. Ecol. Monogr. 51:21-41.

Yahner, R.L. 1983. Seasonal dynamics, habitat relationships, and management of avifauna in farmstead shelterbelts. J. Wildl. Manage. 47:85-104.

Zar, J.H. 1984. Biostatistical analysis, $2^{\text {nd }}$ ed. Prentice Hall, Englewood Cliffs, N.J. 